\title{
Acute phase proteins and total antioxidant capacity in free- roaming cats infected by pathogenic leptospires
}

Andrea Murillo Picco ( $\sim$ dianaandrea.murillo@e-campus.uab.cat)

Universitat Autonoma de Barcelona https://orcid.org/0000-0002-7630-6116

Rafaela Cuenca

Universitat Autonoma de Barcelona

Emmanuel Serrano

Universitat Autonoma de Barcelona

Asta Tvarijonaviciute

Universidad de Murcia

José Cerón

Universitat Autonoma de Barcelona

Goris Marga

Universiteit van Amsterdam

Ahmed Ahmed

Universiteit van Amsterdam

Josep Pastor

Universitat Autonoma de Barcelona

\section{Research article}

Keywords: Albumin, Cat, Haptoglobin (Hp), Leptospira spp., Paraoxonase-1 (PON1), Principal Component Analysis (PCA), Serum Amyloid (SAA) and Total Antioxidant Capacity (TAC).

Posted Date: December 11th, 2020

DOI: https://doi.org/10.21203/rs.3.rs-44167/v2

License: (c) (i) This work is licensed under a Creative Commons Attribution 4.0 International License. Read Full License 


\section{Abstract}

Background: Leptospirosis is a neglected but widespread zoonotic disease throughout the world. The vast majority of mammals are hosts of Leptospira spp., including domestic cats, species in which no consensus has been reached on the clinical presentation or diagnosis of the disease. The study of acute-phase proteins (APPs) and biomarkers of oxidative status would contribute to knowledge about the course of the disease in cats. In this report, we evaluated four APPs: Serum amyloid A-SAA, Haptoglobin-Hp, albumin and Paraoxonase 1-PON1 and the antioxidant response through Total Antioxidant Capacity-TAC, in 13 free-roaming cats naturally infected by pathogenic leptospires and 19 leptospires-free cats, through a Principal Component Analysis (PCA).

Results: The PCA retained two principal components (PC1 and PC2), explaining $60.1 \%$ of the observed variability of the inflammatory proteins and the antioxidant TAC. PC1 was mainly associated with an inflammatory process, whereas PC2 correlated with the antioxidant status. The most contributing variables in PC1 where albumin (27.46\%), SAA (24.71\%), Hp (21.56\%) and PON1 (20.69\%). Variables with significant contribution to the PC2 were the antibody titre against Leptospira spp. (48.41\%) and TAC (35.04\%). Overall, the PCA revealed differences in inflammatory and antioxidant biomarkers in cats naturally infected with leptospires compared to leptospires-free cats.

Conclusions: Increases in Serum SAA, Hp, and decreases in serum albumin concentrations and PON1 activity indicate an acute phase response in infected, DNA positive cats. Moreover, we found an increase in TAC serum concentrations indicating an antioxidant response in this infection, which was proportional to the antibody titre and not to the presence of bacterial DNA.

\section{Background}

Leptospirosis caused by a spirochaetal bacterium of the genus Leptospira is a common and widely distributed zoonoses affecting livestock, domestic, and wild animals throughout the world [1]. A wide variety of mammalian species may be susceptible to Leptospira spp. infection including domestic cats [2] in America [3-5], Asia [6-7], Australia [8] and Europe [910].

Whilst, Leptospira spp. infection in cats has been suspected for some time [11], however, it was two decades before confirmed by microagglutination test (MAT) and PCR [12-13]. Nowadays, the role of cats as a reservoir host to Leptospira spp., is well established [12,14-17].

Leptospires spread throughout the entire body, reproducing in different organs such as the kidneys, liver, central nervous system, eyes, and reproductive system. In cats, most of the Leptospira spp. infections are asymptomatic and unspecific and rarely results in severe organ damage [18]. Few works have described clinical signs related to the infection in cats (e.g., renal injury) $[4,12,16,19]$, most of them being nonspecific [17,20-21]. As a result, there is no consensus on the clinical presentation, development and diagnosis of leptospirosis in domestic cats. Hence ancillary tests inflammatory proteins and biomarkers of oxidative status could, useful to identify the active state of the infection in cats.

Acute-phase proteins (APPs) are increasingly used as tools for the detection of inflammatory diseases in veterinary clinical practice. Use of APP profiles involving at least a major protein (proteins that increase 10-100-fold during the inflammatory response), a moderate protein (increase two-10 fold) and a negative protein (fall in concentration) is highly recommended to differentiate between pathologic states [22]. APPs are species-specific; in cats, Serum Amyloid A (SAA) is a major acute protein, Haptoglobin $(\mathrm{Hp})$ is a positive moderate one acute phase protein, and albumin and paraoxonase-1 (PON1) [22-26] are negatives ones acute phase proteins, with the latest also considered a biomarker of oxidative stress [27]. Several investigations have been carried out concerning the usefulness of APPs in infectious diseases in cats, providing valuable information [28-30]. 
To date, no work has observed the relationship between leptospirosis and APPs in cats. In dogs, however, C-reactive protein/ Haptoglobin ratio (CRP/Hp) and albumin serum concentrations increase after Leptospira interrogans Australis serogroup infection [31].

Biomarkers of redox status have been studied in cats since they may contribute to morbidity in many diseases [30,32-35]. Oxidative stress is defined as reactive oxygen species (ROS) over antioxidant defence mechanisms. It can result from an excess of ROS, a reduction in antioxidants, or both [35]. The measurement of the redox status in companion animals has been addressed with novel approaches in the last few years using the TAC assay [35-36]. TAC represents the sum of the activities of the different antioxidants and the antioxidative effects provided by the interactions between individual antioxidants [37-38], also used to evaluate the antioxidant response. Cats seem to be more susceptible to oxidative stress and damage, probably due to the presence of eight reactive and fragile sulfhydryl groups on its haemoglobin molecule and to the particular splenic structure of the species [39-40].

The objective of this paper was to evaluate a panel of acute Phase Proteins (APPs: Serum Amyloid A -SAA, Haptoglobin Hp, Paraoxonase1 -PON1 and Albumin) and Total Antioxidant Capacity -TAC in free-roaming cats naturally infected by pathogenic leptospires using a principal component analysis (PCA).

\section{Methods}

\section{Selection of cases}

Thirty-two serum samples from domestic short-haired cats that had been collected during a previous study on Leptospira spp. prevalence in cats in Spain were used in the current study [10]. Cats were part of a free-roaming cat spay program and shelter's animals neutering program. Blood samples were taken under anaesthesia for neutering. Sampling collection was performed under the guidelines of the Ethical Committee Animal Care and Research, Autonomous University of Barcelona, approval number CEEAH, code 2939. Besides, written informed consent was obtained from the shelters to use the animals in the study.

Serum samples were stored at $-80^{\circ} \mathrm{C}$ until analysis. MAT was performed by direct reading following a technique described before [41]. DNA extracted from cats' biological materials were tested with TaqMan real-time PCR described by Ahmed et al., 2020 [42].

Samples were divided into three groups: Group $1(n=8)$, cats positive to anti-leptospiral antibodies detected by a MAT consisting of 27 serovars, belonging to 20 serogroups and 8 species of Leptospira. Pathogenic Leptospira spp. DNA in urine or blood was not detected in these cats. Group $2(\mathrm{n}=5)$, cats positive to Leptospira spp. DNA detected by PCR in blood or urine. These cats had no antibodies against Leptospira spp. Group 3 or control group $(n=19)$, sera from leptospires-free cats. The absence of Leptospira spp. infection in the animals of this group was verified by serology (negative antibodies against Leptospira spp. by MAT) and PCR of blood and urine (negative leptospiral DNA amplification). All animals in the study $n=32$, were tested against feline immunodeficiency and leukaemia viruses (SNAP FIV/FeLV Combo Test ${ }^{\circledR}$ ). According to the medical record, all animals in the present study were free-roaming cats and had unremarkable findings upon physical exam.

\section{APPs analysis}

SAA: Serum amyloid A concentrations were determined by a human turbidimetric immunoassay (LZ-SAA; Eiken Chemical Co., Tokyo, Japan), adapted to an automated analyser (Olympus 2700). This method had been previously validated for use in cats [43]. Serum concentrations lower than $5 \mu \mathrm{g} / \mathrm{ml}$ were considered normal for cats; the limit of detection was set at $0.38 \mu \mathrm{g} / \mathrm{ml}$ [44]. 
Hp: Serum Haptoglobin concentrations were determined by the use of the haemoglobin-binding method with a commercial kit (Tridelta Development Ltd., Brey, Ireland). The method was previously validated for use in cats [45]. Serum concentrations lower than $3 \mathrm{~g} / \mathrm{L}$ were considered normal; the limit of detection considered was $0.0088 \mathrm{~g} / \mathrm{L}$.

Albumin: Serum albumin was determined using a commercially available kit (Albumin OSR 6102; Olympus Life and Material Science Europe $\mathrm{GmbH}$, Irish branch, Ennis, Ireland) following instructions of the manufacturer.

PON1. Serum PON1 activity was determined by measuring the hydrolysis of p-nitrophenyl acetate to p-nitrophenol, following a previously described method [46], validated in cats [45]. The rate of formation of $p$-nitrophenol was determined at $405 \mathrm{~nm}$ after 250 seconds in an automated chemistry analyser (Olympus 2700). The limit of detection was $0.3 \mathrm{IU} / \mathrm{ml}$. Serum concentrations between 3.8 to $7.3 \mathrm{lU} / \mathrm{ml}$ were considered normal for cats $[27,45]$.

\section{Antioxidant analysis}

TAC: Total antioxidant capacity was determined by the assay Trolox equivalent antioxidant capacity (TEAC1). It is based on the principle that when ABTS (2,2'-azino-bis (3-ethylbenzo-thiazoline-6-sulfonate acid) is incubated with a proper chemical an ABTS radical (ABTS*) is formed, previously described for humans [36] and validated for cats [27]. Serum concentrations higher than $0.35 \mathrm{mmol} / \mathrm{L}$ were considered normal; the limit of detection considered was $0.02 \mathrm{mmol} / \mathrm{L}$.

All acute phase proteins and antioxidant analyses were performed on an automated biochemistry analyser (Olympus AU600, Olympus Diagnostic, $\mathrm{GmbH}$ ).

\section{Statistical analysis}

Principal component analysis (PCA) is a dimensionality reduction technique using a linear transformation applied to multidimensional data. The original set of variables (e.g., our set of inflammatory markers, the antioxidant biomarker and antibody titres against Leptospira spp.), is reduced to a smaller number of derived variables that may be readily visualised in 2- or 3-principal components containing the highest observed variance. These derived variables can then be compared between categorical variables (e.g., Leptospira spp. infection status), through a Student t-test. Median, SD, interquartile range and range (min-max) of our quantitative variables were also calculated. PCA analysis was performed using the libraries "car" 3-0-6 version [47] "FactomineR" 2.2 version [48], "factoextra" 1.0.6 version [49] and "ggplot2" 3.2.1 version [50] of the R Statistical software 3.6.2 version [51].

\section{Results}

\section{Baseline characteristics of the cats}

The 32 serum samples included in the study comprised 11 females and 21 males between 6 months to 12.5 years old. The final distribution in the groups was 1 female and 7 males (ranging from 6 months to 7 years old) in Group 1 (antileptospiral antibodies); 3 females and 2 males (ranging from 6 months to 1 year old) in Group 2 (positive Leptospira spp. DNA in blood or urine) and 7 females and 12 males (ranging from 6 months to 12.5 years old) in Group 3 (leptospires-free cats or control group). Only one cat, included in Group 1, was FIV positive; all others were negative for both FIV/FeLV. More details about the distribution of the groups and the involved serovars (Group 1) are shown in Table 1 and Table 2.

Table 1. Distribution of groups in cats naturally infected by leptospires and leptospires-free cats. 


\begin{tabular}{|c|c|c|c|c|c|}
\hline & & $\begin{array}{c}\text { Total population } \\
n: 32\end{array}$ & $\begin{array}{c}\text { Group } 1 \\
n: 8\end{array}$ & $\begin{array}{c}\text { Group } 2 \\
n: 5\end{array}$ & $\begin{array}{c}\text { Group } 3 \\
n: 19\end{array}$ \\
\hline \multirow[t]{2}{*}{ Gender } & Male & 21 & 7 & 2 & 12 \\
\hline & Female & 11 & 1 & 3 & 7 \\
\hline \multirow{3}{*}{$\begin{array}{l}\text { Age } \\
(y .0 .)\end{array}$} & Mean & 2.6 & 2.7 & 0.63 & 3.0 \\
\hline & Min-Max & $0.5-12.5$ & $0.5-7$ & $0.5-1$ & $0.5-12.5$ \\
\hline & $\mathrm{SD}$ & 3 & 2.43 & 0.21 & 3.46 \\
\hline
\end{tabular}

y.o.= years old, (group 1) = anti-leptospiral antibodies (group 2) = positive Leptospira spp. DNA in blood or urine, (group 3) = leptospires-free cats or control group.

Table 2. Description of leptospiral serovars and PCR results by group of cats

\begin{tabular}{|c|c|c|c|c|c|}
\hline & Cat & Gender & $\begin{array}{c}\text { Group } 1 \\
n: 8\end{array}$ & $\begin{array}{c}\text { Group } 2 \\
n: 5\end{array}$ & $\begin{array}{c}\text { Group } 3 \\
n: 19\end{array}$ \\
\hline \multirow{10}{*}{$\begin{array}{l}\text { Infecting } \\
\text { leptospiral } \\
\text { serovars }\end{array}$} & & & Serovar and titre & \multirow[t]{10}{*}{ Seronegative } & \multirow[t]{10}{*}{ Seronegative } \\
\hline & 1 & Female & Ballum 1:20 & & \\
\hline & $2 *$ & Male & Bratislava 1:20 & & \\
\hline & & & Cynopter1 1:20 & & \\
\hline & 3 & Male & Cynopteri 1:20 & & \\
\hline & 4 & Male & Cynopteri 1:20 & & \\
\hline & 5 & Male & Cynopteri 1:40 & & \\
\hline & 6 & Male & Ballum 1:20 & & \\
\hline & 7* & Male & $\begin{array}{c}\text { Pomona } 1: 20 \\
\text { Proechimys } 1: 20\end{array}$ & & \\
\hline & 8 & Male & Sejroe 1:20 & & \\
\hline PCR & 5 cats & $\begin{array}{l}3 \text { Female } \\
2 \text { Male }\end{array}$ & Negative & $\begin{array}{l}1 \text { in blood } \\
4 \text { in urine }\end{array}$ & Negative \\
\hline
\end{tabular}

$($ group 1$)=$ anti-leptospiral antibodies $($ group 2) = positive Leptospira spp. DNA in blood or urine, $($ group 3$)=$ leptospires-free cats or control group. *Cat positive to more than one serovar.

Serum concentrations of APPs, TAC and antibody titre against Leptospira spp. obtained in the different groups of the study are shown in Table 2. No concentrations lower than the limit of detection for any of the APPs and TAC studied were obtained.

Table 3. Serum concentrations of APPs, TAC and anti-leptospiral antibody titre. (mean, minimum and maximum and IQR) in cats naturally infected by leptospires (Groups 1 and 2) and leptospires-free (Group 3). 


\begin{tabular}{|c|c|c|c|c|c|c|}
\hline & $\begin{array}{c}\text { SAA } \\
(\mu \mathrm{g} / \mathrm{ml})\end{array}$ & $\begin{array}{l}\mathrm{Hp} \\
(\mathrm{g} / \mathrm{l})\end{array}$ & $\begin{array}{l}\text { Albumin } \\
(\mathrm{g} / \mathrm{l})\end{array}$ & $\begin{array}{c}\text { PON1 } \\
\text { (IU/ml) }\end{array}$ & $\begin{array}{c}\text { TAC } \\
(\mathrm{mmol} / \mathrm{l})\end{array}$ & Antibody titre \\
\hline \multirow{3}{*}{$\begin{array}{l}\text { Group } 1 n=8 \\
\text { MEAN } \\
\text { Min-Max } \\
\text { IQR }\end{array}$} & 0.62 & 4.05 & 2.86 & 3.91 & 0.64 & 22.5 \\
\hline & $0.10-1.60$ & $2.49-6.29$ & $2.31-3.3$ & $1.87-6.02$ & $0.46-0.80$ & $20-40$ \\
\hline & 0.82 & 1.23 & 5.3 & 1.33 & 0.15 & 0 \\
\hline \multirow{3}{*}{$\begin{array}{l}\text { Group } 2 n=5 \\
\text { mEAN } \\
\text { Min-Max } \\
\text { IQR }\end{array}$} & 0.17 & 4.47 & 2.70 & 3.05 & 0.53 & 0 \\
\hline & $0.1-0.20$ & $1.97-8.11$ & $2.12-3.22$ & $0.14-4.84$ & $0.43-0.70$ & 0 \\
\hline & 0.05 & 2.03 & 5.2 & 0.86 & 0.1 & 0 \\
\hline \multirow{3}{*}{$\begin{array}{l}\text { Group } 3 n=19 \\
\text { meAN } \\
\text { Min-Max } \\
\text { IQR }\end{array}$} & 1.43 & 3.60 & 3.20 & 5.35 & 0.58 & 0 \\
\hline & $0.10-6.00$ & $1.64-4.89$ & $2.48-4.49$ & $3.40-7.41$ & $0.44-0.7$ & 0 \\
\hline & 1.25 & 1.68 & 4.4 & 1.43 & 0.12 & 0 \\
\hline
\end{tabular}

Min $=$ Minimum, Max = Maximum, IQR= Interquartile range, SAA= serum amyloid A, Hp= haptoglobin, PON1 = Paraoxonase1, TAC $=$ Total antioxidant capacity, $($ group 1) $=$ anti-leptospiral antibodies (group 2) = positive Leptospira spp. DNA in blood or urine, (group 3) = leptospires-free cats or control group.

\section{Principal component analysis}

Our PCA retained two principal components (PC1 and PC2), explaining $60.1 \%$ of the observed variability of our set of inflammatory proteins and antioxidant biomarker. PC1 and PC2 accounted for $35.2 \%$ and $24.9 \%$ of the observed variance and were mainly associated with the inflammatory process and the antioxidant response, respectively (Table 4 and Fig. 1). The most contributing variables in the PC1 were albumin, SAA, HP, and PON1, whereas anti-leptospiral antibodies and serum concentration of TAC did not contribute significantly to the first dimension of our PCA (Table 4). Regarding PC2, anti-leptospiral antibodies and the total antioxidant capacity were the essential variables in terms of contribution to the component (Table 4 and Fig. 2).

The presence of pathogenic Leptospira spp. DNA in blood or urine (positive or negative) was a supplementary variable significantly related to PC1 but not to PC2 (Table 4). On the other hand, the presence of antibodies against Leptospira spp. by MAT (positive or negative) was a supplementary variable correlated to PC2 but not to PC1 (Table 4).

Table 4. Contribution of variables to PCA and dimensions description 


\begin{tabular}{|l|c|c|c|c|c|c|}
\hline & \multicolumn{3}{|c|}{ PC1 } & \multicolumn{3}{c}{ PC2 } \\
\hline Active variables & Contribution (\%) & Correlation & $\boldsymbol{P}$-value & Contribution (\%) & Correlation & $P$-value \\
\hline Albumin & $\mathbf{2 7 . 4 6}$ & 0.76 & $4.07 \mathrm{e}^{-07}$ & 0.28 & -0.06 & $>0.05$ \\
\hline SAA & $\mathbf{2 4 . 7 1}$ & -0.72 & $2.9 \mathrm{e}^{-06}$ & 11.72 & -0.42 & $1.7 \mathrm{e}-02$ \\
\hline Hp & $\mathbf{2 1 . 5 6}$ & -0.67 & $2.26 \mathrm{e}^{-05}$ & 0.16 & 0.05 & $>0.05$ \\
\hline PON1 & 20.69 & 0.66 & $3.71 \mathrm{e}^{-05}$ & 4.38 & -0.26 & $>0.05$ \\
\hline Antibody titre & 3.07 & -0.25 & $>0.05$ & $\mathbf{4 8 . 4 1}$ & 0.85 & $7.64 \mathrm{e}^{-}$- \\
\hline TAC & 2.51 & 0.23 & $>0.05$ & $\mathbf{3 4 . 0 5}$ & 0.72 & $2.95 \mathrm{e}^{-06}$ \\
\hline Supplementary variables & Contribution (\%) & $\mathbf{R}^{2}$ & $\boldsymbol{P}$-value & Contribution (\%) & $\mathbf{R}^{2}$ & $\boldsymbol{P}$-value \\
\hline MAT (+/-) & na & na & $>0.05$ & n/a & 0.62 & 0.005 \\
\hline PCR (+/-) & na & 0.22 & 0.006 & n/a & $>0.05$ & $>0.05$ \\
\hline
\end{tabular}

Contribution of the inflammatory biomarkers (Albumin, Hp and SAA and PON1), antioxidant biomarker (TAC) and antileptospiral antibodies (titre) to the first (PC1) and second (PC2) dimensions of principal component analysis, exploring the response of cats naturally infected by pathogenic leptospires and leptospires-free cats. The outcomes of the MAT test (+/-) and the amplification of pathogenic Leptospira spp. DNA through a PCR analysis (+/-) were considered supplementary variables, i.e., not considered for the construction of the factorial axes but used to test statistical differences in the PCA scores. The "na" acronym indicates not applicable.

\section{Discussion}

It is known that cats can sporadically suffer from leptospirosis [12,16,17], but while the clinical presentation of the disease is rare, it may be missed [2]. Asymptomatic cats can shed the bacteria through urine [9,15], and unlike infected dogs, antibody titres against Leptospira spp. detected in sub-clinically infected animals are low in the species [6-7,20]. Cats infected by Leptospira spp. may become an incidental or reservoir host. The incidental host develops an acute disease state with mild to moderate clinical signs, leptospiraemia (1-7 days/sub-acute state), leptospires urinary shedding (10 dayabout a month/late acute state) and antibodies titres. Reservoir cats usually exhibit a chronic state of infection and have no clinical signs of disease or leptospiraemia, but they do have long-term and intermittent leptospires urinary shedding and low or absent antibodies titres [21].

APPs analysis has been studied in cats with infectious diseases [27-28,52-53] and its use is highly recommended to determine the active state of disease. TAC as an antioxidant biomarker can contribute to the morbidity of many diseases and is likely to become, along with APPs, an important component in the active state detection of diseases, including leptospirosis in cats.

A PCA statistical approach is based on the fact that cats naturally infected by Leptospira spp. may be grouped into different patterns that may be associated with different serum concentrations of APPs and TAC as antioxidant biomarkers. The information obtained could facilitate the understanding of the pathogenesis of Leptospira spp. and infection course in cats.

PC1, accounting for $35.23 \%$ of the data variance, was significantly associated with the APPs profile or inflammatory pattern. The supplementary qualitative variable PCR (negative/positive) was significant in the PC1 ( ${ }^{2} 0.22, P$-value 0.006 ), suggesting a direct relationship between the presence of the bacteria in blood or urine and the APPs responses. 
Patterns of inflammation described in preliminary works were determined and confirmed by our PCA analysis in PCR positive cats (blood or urine). They include a positive correlation found between SAA and Hp (-0.72 and -0.67 respectively), albumin and PON1 (0.76 and 0.66 respectively) [30,54], and negative correlation between SAA-Hp and albumin-PON1 [5455]. It is well known that albumin falls gradually with extensive inflammation, with the reduction in concentration being more noticeable in chronic inflammatory disease [56]. Serum PON1activity was associated with a negative APP and did not play a role as a biomarker of oxidative status in PC1 or PC2, in contrast to previous studies $[27,57]$.

Likewise, based on Leptospira spp. pathogenesis, it is possible to assume that PCR positive animals had a sub-acute infection status (Leptospira spp. present in blood/ early stage of the infection) or were mostly reservoirs (Leptospira spp. present in urine/intermittent urinary shedding). Based on the PC1 results, animals of group 2 reflected an active infection, compared to those infected with anti-leptospiral antibodies (group 1), which did not reflect an active state of infection. The difference in inflammatory patterns between the two groups of infected cats its very likely due to differences in bacterial load and the infecting serovar involved, among others. In diseases such as FIV, the relationship between antigenic load and high serum levels of APPs, and more specifically SAA, has been shown [58]. Likewise, Leptospira serovars involved in the infection have also been reported to influence the inflammatory response in other species. In dogs, it has been shown that serogroup Pomona [59] and Icterohaemorrhagiae [2] trigger the strongest inflammatory responses and have the worst prognosis. In cats, this remains poorly understood [21]. In our study, the infecting serovar or serogroup was not detected in the PCR positive cats as they had no anti-leptospiral antibodies.

PC2, accounting for $24.9 \%$ of the data variance, was significantly associated with the oxidative status pattern. A positive correlation was found between antibody titre and serum concentration of TAC ( 0.85 and 0.72 , respectively) with PC2; thus, is very likely that as antibody titres against Leptospira spp. increased, endogenous antioxidant synthesis increased as well. Likewise, the supplementary qualitative variable MAT (+/-) was significant in the PC2 $\left(\mathrm{R}^{2} 0.62, P\right.$-value $\left.<0.05\right)$.

Cats with low anti-leptospiral antibodies titre (ranging from 1:20 1:40), probably at a resolution stage of infection, had increases in serum concentrations of TAC, most likely, to counteract the oxidative state associated with the inflammation. In human and companion animals, it has been reported that high serum concentrations of TAC are due to counteracting the increases in oxidants, while decreases are attributed to a persistent state of oxidative stress $[27,38,60]$.

Seropositive cats seemed to be at risk of developing oxidative stress as antioxidant response measured by the TEC 1 assay was above the cut-off point, unlike DNA positive animals. Considering that one of the 8 seropositive cats, also tested positive for FIV infection, it is likely that in this cat the TAC serum values were also increased by the co-infection with the virus.

Antibody titres, in which the antioxidants become exhausted, showing a decrease in serum concentration of TAC and leading to an oxidative status [30], are not yet established. The little information available for cats has used serum concentrations of TAC to assess the antioxidant components globally. Some authors have reported a decrease in serum concentrations of TAC associated with oxidative stress [27, 30, 55, 61].

Despite the positive correlation found in our study between antibody titres against Leptospira spp. and serum concentrations of TAC with PC2, it is not possible to establish whether the variation in the serum concentration of TAC obtained in the two groups of animals naturally infected by Leptospira spp. (Group 1 and 2) is due to the inflammatory response caused by Leptospira spp. infection or whether this is due to the differences in the available assays for measuring TAC [57].

Infectious diseases other than VIF/ViLEF were not ruled out. As mentioned above, diseases such as feline infectious peritonitis (FIP) [27,28], FIV [34] and haemoplasmas [53] have also shown an increase in some of these biomarkers. As well as non-infectious inflammatory diseases $[32,43,54]$. In the present study, Cats health status was based on physical exam findings and biochemistry, so these results need to be interpreted with caution. 
One of the limitations of our study is the small sample size (total and by groups), and the lack of follow up of the serum values of the biomarkers measured, due to the nature of the animals in the study.

Further studies should be undertaken to elucidate, the Leptospira serovars role

in cats and their involvement in the inflammatory response through serum concentrations of APPs and TAC as oxidative stress markers by using different assays and enzymes implied in the antioxidant response. To the authors' knowledge, this is the first report measuring the serum concentration of APPs and TAC in cats naturally infected by pathogenic leptospires.

Finally, based on PCA analysis results and the PON-1 arrangement on the inflammatory PC1, further experimental studies are needed to estimate its importance as a negative APP in cats.

\section{Conclusions}

The use of APPs in Leptospira spp. DNA positive cats help to identify the active state of infection. Leptospira spp. DNA positive, are not at risk of developing oxidative stress. Cats with anti-leptospiral antibodies did not reflect an active inflammatory pattern but instead indicate an antioxidant response in this infection, which is proportional to the antibody titre.

To conclude, this study provides additional information to the limited data available on the use of acute phase proteins and TAC in cats naturally infected by leptospires, which could be helpful for the understanding and diagnosis of leptospirosis in cats.

\section{Abbreviations}

APPs: Acute phase proteins, CBC: Complete blood count, CRP/Hp: C reactive protein-Haptoglobin ratio, DNA: Deoxyribonucleic acid, FeLV: Feline leukaemia virus, FIV: Feline infectious virus, GPox: glutathione peroxidase, Hp: Haptoglobin, IQR: Interquartile ranges, LPS: Lipopolysaccharides, MAT: Micro agglutination test, PC1: Principal component 1, PC2: Principal component 2, PCA: Principal components Analysis, PCR: Polymerase chain reaction, pNA: p-nitrophenyl acetate, PON1:Paraoxonase1, ROS: Reactive oxygen species, SAA: Serum amyloid A, SOD: Superoxide dismutase, TAC: Total antioxidant capacity, TEAC1: Trolox equivalent antioxidant capacity.

\section{Declarations}

\section{Ethics approval and consent to participate}

Sampling collection was performed under the guidelines of the Ethical Committee Animal Care and Research, Autonomous University of Barcelona, approval number CEEAH, code 2939. Besides, written informed consent was obtained from the shelters to use the animals in the study.

\section{Consent for publication}

Not applicable

\section{Availability of data and materials}

The datasets used and/or analysed during the current study are available from the corresponding author on reasonable request.

\section{Competing interests}


The authors declare that they have no competing interests

\section{Funding}

Emmanuel Serrano was funded by the Spanish Ministerio de Economia y Competitividad (MINECO) through a Ramon y Cajal agreement (RYC-2016-21120).

\section{Authors' contributions}

All authors read and approved the final manuscript. Study design: AM, RC, JP. Data collection: AM, MG, AA, AT, JC. Statistical analysis: AM, ES, JP. Technical review, interpretation of the data and preparation of this manuscript: AM, RC, ES, JP, AT, JC.

\section{Acknowledgements}

Not applicable

\section{Author's information}

${ }^{1}$ Wildlife Ecology \& Health group (WE\&H), Departament de Medicina i Cirurgia Animals. Universitat Autònoma de Barcelona (UAB), Bellaterra, España.

${ }^{2}$ Servei d'Ecopatologia de Fauna Salvatge (SEFaS). Universitat Autònoma de Barcelona (UAB), Bellaterra, España.

${ }^{3}$ Interdisciplinary Laboratory of Clinical Analysis Interlab-UMU, University of Murcia, Murcia, Spain.

${ }^{4}$ OIE and National Collaborating Centre for Reference and Research on Leptospirosis (NRL), Amsterdam UMC, University of Amsterdam, Medical Microbiology, Meibergdreef 39, 1105 AZ Amsterdam, the Netherlands.

\section{References}

1. Levett, N. Leptospirosis. Clin. Microbiol. 2001, 14, 296-326. https://doi.org/10.1128/CMR.14.2.296-326.2001.

2. Adler, Current Topics in Microbiology and Immunology, 1st ed.; Springer: Berlin/Heidelberg, Germany, 2014.

3. Azócar-Aedo, ; Monti, G.; Jara, R. Leptospira spp. in domestic cats from different environments: Prevalence of antibodies and risk factors associated with the seropositivity. Animals 2014, 4, 612-626. https://doi:10.3390/ani4040612.

4. Rodriguez, ; Lapointe, C.; Arsenault, J.; Carioto, L.; Harel, J. Serologic and urinary PCR survey of leptospirosis in healthy cats and in cats with kidney disease. J. Vet. Intern. Med. 2014, 28. https://doi:10.1111/jvim.12287.

5. Markovich, E.; Ross, L.; McCobb, E. The prevalence of leptospiral antibodies in free roaming cats in Worcester County, Massachusetts. J. Vet. Int. Med. 2012, 26, 688-689. https://doi:10.1111/j.1939-1676.2012.00900.

6. Spribler, ; Jongwattanapisan, P.; Luengyosluechakul, S.; Pusoonthornthum, R.; Prapasarakul, N.; Kurilung, A; et al. Leptospira infection and shedding in cats in Thailand. Transbound. Emerg. Dis. 2019, 66, 948-956. https://doi:10.1111/tbed.13110.

7. Alashraf, A. R.; Lau, S. F.; Khairani-Bejo, S.; Khor, K. H.; Ajat, M.; Radzi, R.; et al. First report of pathogenic Leptospira spp. isolated from urine and kidneys of naturally infected cats. Plos One 2020, 15, 1-13. https://doi.org/10.1371/journal.pone.0230048.

8. Dybing, A.; Jacobson, C.; Irwin, P.; Algar, D.; Adams, P.J. Leptospira species in feral cats and black rats from western Australia and Christmas Island. Vector Borne Zoonotic Dis. 2017, 17, 319-324. https://doi:10.1089/vbz.2016.1992. 
9. Weis, ; Rettinger, A.; Bergmann, M.; Llewellyn, J.R.; Pantchev, N.; Straubinger, R.K.; et al. Detection of Leptospira DNA in urine and presence of specific antibodies in outdoor cats in Germany. J. Feline Med. Surg. 2017, 19, 470-476. https://doi:10.1177/1098612X16634389.

10. Murillo, A.; Cuenca, R.; Serrano, E.; Marga, G.; Ahmed, A.; Cervantes, S.; et al. Leptospira Detection in Cats in Spain by Serology and Molecular Techniques. International Journal of Environmental Research and Public Health 2020, 17, 113. https://doi.org/10.3390/ijerph17051600.

11. Agunloye, A.; Nash, A.S. Investigation of possible leptospiral infection in cats in Scotland. J. Small Anim. Pract. 1996, $37,126-129$.

12. Arbour, ; Blais, M.-C.; Carioto, L.; Sylvestre, D. Clinical leptospirosis in three cats (2001-2009). J. Am. Anim. Hosp. Assoc. 2012, 48, 256-260. https://doi:10.5326/JAAHA-MS-5748.

13. Desvars, ; Naze, F.; Benneveau, A.; Cardinale, E.; Michault, A. Endemicity of leptospirosis in domestic and wild animal species from Reunion Island (Indian Ocean). Epidemiol. Infect. 2013, 141, 1154-1165.

doi:10.1017/S0950268812002075.

14. Dorsch, ; Salgado, M.; Monti, G.; Avilez, C.; Collado, B.; Tomckoviack, C.; et al. Urine shedding of pathogenic Leptospira spp. in cats in southern chile in science for people. In Proceedings of the 10th International Leptospirosis Society Conference, Palmerston North, New Zealand, 27 November-1 December 2017; p. 227.

15. Chan, -W.; Hsu, Y.-H.; Hu, W.-L.; Pan, M.-J.; Lai, J.-M.; Huang, K.-C.; et al. Serological and PCR detection of feline Leptospira in Southern Taiwan. Vector Borne Zoonotic Dis. 2014, 14, 118-123.

https://doi:abs/10.1089/vbz.2013.1324.

16. Ojeda, J.; Salgado, M.; Encina, C.; Santamaria, C.; Monti, G. Evidence of interspecies transmission of pathogenic Leptospira between livestock and a domestic cat dwelling in a dairy cattle farm. Vet. Med. Sci 2018, 80, 1305-1308. https://doi:10.1292/jvms.16-0361.

17. Beaudu-Lange, ; Lange, E. Unusual clinical presentation of leptospirosis in a cat. Rev. Vet. Clin. 2014, 49, 115-122. https://doi:Org/10.1016/j.anicom.2014.05.001.

18. Craig E, Greene, JE, Sykes, et al. Leptospirosis. In: Greene CE (ed). Infectious diseases of the dog and cat. 4th ed. St Louis, MO: Elsevier, 2015, pp 431-447.

19. Shropshire, ; Veir, J.K.; Morris, A.K.; Lappin, M.R. Evaluation of the Leptospira species microscopic agglutination test in experimentally vaccinated cats and Leptospira species seropositivity in aged azotemic client owned cats. J. Feline Med. Surg. 2016, 18, 768-772. https://doi:org/10.1177/1098612X15593902.

20. Mylonakis, E.; Bourtzi-Hatzopoulou, E.; Koutinas, A.F.; Petridou, E.; Saridomichelakis, M.N.; Leontides, L.; et al. Leptospiral seroepidemiology in a feline hospital population in Greece. Vet. Rec. 2005, 156, 615-616.

21. Murillo, ; Goris, M.; Ahmed, A.; Cuenca, R.; Pastor, J. Leptospirosis in cats: Current literature review to guide diagnoses and management. J. Feline Med. Surg. 2020, 22, 216- https://doi:10.1177/1098612X20903601.

22. Ceron, J. J.; Eckersall, P. D.; and Martýnez-Subiela, S. Acute phase proteins in dogs and cats: current knowledge and future perspectives. Vet Clin Patho/ 2005, 34, 85-99. https://doi:10.1111/j.1939-165x.2005.tb00019.x.

23. Eckersall, P. D and Bell, R. Acute phase proteins: Biomarkers of infection and inflammation in veterinary medicine. The Vet J 2010, 185, 23-27. https://doi.org/10.1016/j.tvjl.2010.04.009.

24. Feingold, K. R.; Memon, R. A.; Moser, A. H and Grunfeld, C. Paraoxonase activity in the serum and hepatic mRNA levels decrease during the acute phase response. Atherosclerosis 1998, 139, 307-315. https://doi.org/10.1016/S00219150(98)00084-7.

25. Dullaart, R. P. F.; De Vries, R.; Sluiter, W. J and Voorbij, H. A. M. High plasma C-reactive protein (CRP) is related to low paraoxonase-I (PON-I) activity independently of high leptin and low adiponectin in type 2 diabetes mellitus. Clin Endocrino/ 2009, 70, 221-226. https://doi.org/10.1111/j.1365-2265.2008.03306.x.I 
26. Vilhena, H.; Tvarijonaviciute, A., Cerón, J. J., Vieira, L., Pastor, J and Silvestre-Ferreira, A. C. Acute phase proteins response in cats naturally infected with Hepatozoon felis and Babesia vogeli. Vet Clin Pathol 2017, 46, 72-76. https://doi.org/10.1111/vcp.12451.

27. Tecles, F.; Caldín, M., Tvarijonaviciute, A., Escribano, D., Martínez-Subiela, S and Cerón, J. J. Serum biomarkers of oxidative stress in cats with feline infectious peritonitis. Res Vety Sci 2015, 100, 12-17. https://doi.org/10.1016/j.rvsc.2015.02.007.

28. Giordano, A.; Spagnolo, V.; Colombo, A and Paltrinieri, S. Changes in some acute phase protein and immunoglobulin concentrations in cats affected by feline infectious peritonitis or exposed to feline coronavirus infection. Vet J 2004, 167, 38-44. http://doi:10.1016/s1090-0233(03)00055-8.

29. Hazuchova, K.; Held, S.; and Neiger, R. Usefulness of acute phase proteins in differentiating between feline infectious peritonitis and other diseases in cats with body cavity effusions. Feline Med. Surg 2017, 19, 809-816. https://doi.org/10.1177/1098612X16658925.

30. Vilhena, H.; Figueiredo, M.; Cerón, J. J.; Pastor, J.; Miranda, S.; Craveiro, H et al. Acute phase proteins and antioxidant responses in queens with pyometra. Theriogenology 2018, 115, 30-37.

https://doi.org/10.1016/j.theriogenology.2018.04.010.

31. Mastrorilli, C.; Dondi, F.; Agnoli, C., Turba, M. E., Vezzali, E and Gentilini, F. Clinicopathologic features and outcome predictors of Leptospira interrogans Australis serogroup infection in dogs: a retrospective study of 20 cases (20012004). J Vet Intern Med 2007, 21, 3-10. http://wwwdoi.10.1892/0891-6640(2007)21[3:cfaopo]2.0.co;2.

32. Krofič Žel, M.; Tozon, N and Nemec Svete, A. Plasma and Erythrocyte Glutathione Peroxidase Activity, Serum Selenium Concentration, and Plasma Total Antioxidant Capacity in Cats with IRIS Stages I-IV Chronic Kidney Disease. J Vet Intern Med 2014, 281, 130-136. https://doi.org/10.1111/jvim.12264.

33. McMichael, M. A. Oxidative stress, antioxidants, and assessment of oxidative stress in dogs and cats. J Am Vet Med Assoc 2007, 231, 714-720. https://doi.org/10.2460/javma.231.5.714.

34. Webb, C.; Lehman, T.; McCord, K.; Avery, P and Dow, S. Oxidative stress during acute FIV infection in cats. Vet Immunol Immunopatho/ 2008, 122, 16-24. https://doi.org/10.1016/j.vetimm.2007.11.004.

35. Castillo, C.; Pereira, V.; Abuelo, A., Guimarey, R.; García-Vaquero, M.; Benedito, J. L.; et al. Preliminary results in the redox balance in healthy cats: influence of age and gender. Feline Med. Surg 2013, 15, 328-332.

https://doi.org/10.1177/1098612X12467996.

36. Erel, O. A novel automated direct measurement method for total antioxidant capacity using a new generation, more stable ABTS radical cation. Clin Biochem 2004, 37, 277-285. https://doi.org/10.1016/j.clinbiochem.2003.11.015.

37. Ghiselli, A.; Serafini, M., Natella, F and Scaccini, C. Total antioxidant capacity as a tool to assess redox status: Critical view and experimental data. Free Radic Biolo Med 2000, 29, 1106-1114. https://doi.org/10.1016/S08915849(00)00394-4.

38. Rubio, C.P; Hernández-Ruiz, J.; Martinez-Subiela, S.; Tvarijonaviciute, A and Ceron, J. J. Spectrophotometric assays for total antioxidant capacity (TAC) in dog serum: an update. BMC Vet Res 2016, 12, 166.

https://doi.org/10.1186/s12917-016-0792-7.

39. Desnoyers Michel. Anemias Associated with Oxidative Injury. In D. J. and K. J. W. Weiss (Ed.), Schalm's veterinary hematology (Sixth edit, p. 1206). 2010. lowa, USA: Blackwell.

40. Christopher, M. M.; Broussard, J. D and Peterson, M. E. Heinz body formation associated with ketoacidosis in diabetic cats. J Vet Intern Med 1995, 9, 24-31. https://doi.org/10.1111/j.1939-1676.1995.tb03268.x.

41. Goris, M.G.; Hartskeerl, R.A. Leptospirosis serodiagnosis by the microscopic agglutination test. Curr Protoc Microbio. 2014, 32, 12E-5. doi:10.1002/9780471729259

42. Ahmed, A.A.; GorisG.A and Meijer M.C. Development of lipL32 real-time PCR combined with an internal and extraction control for pathogenic Leptospira detection. PLoS One. 2020, 15, 1-11. doi: 10.1371. 
43. Kajikawa, T., Furuta, A., Onishi, T., Tajima, T and Sugii, S. Changes in concentrations of serum amyloid A protein, alpha 1-acid glycoprotein, haptoglobin, and C-reactive protein in feline sera due to induced inflammation and surgery. Vet Immunol and Immunopathol 1999, 68, 91-98. http://wwwdoi.10.1016/s0165-2427(99)00012-4.

44. Hansen, A. E.; Schaap, M. K and Kjelgaard-Hansen, M. Evaluation of a commercially available human serum amyloid A (SAA) turbidimetric immunoassay for determination of feline SAA concentration. Vet Res Commun 2006, 30, 863872. https://doi.org/10.1007/s11259-006-3373-6.

45. Tvarijonaviciute, A.; Ceron, J. J.; Holden, S. L.; Morris, P. J.; Biourge, V and German, A. J. Effects of weight loss in obese cats on biochemical analytes related to inflammation and glucose homeostasis. Domest Anim Endocrinol 2012, 42, 129-141. https://doi.org/10.1016/j.domaniend.2011.10.003.

46. Tvarijonaviciute, A.; Tecles, F.; Caldin, M.; Tasca and Cerón, J. Validation of spectrophotometric assays for serum paraoxonase type-1 measurement in dogs. Am J Vet Res 2012. , 73, 34-41. https://doi.org/10.2460/ajvr.73.1.34.

47. Fox, J and Weisberg, S. An \{R\} Companion to Applied Regression, Third Edition. 2019. Thousand Oaks CA: Sage. URL: https://socialsciences.mcmaster.ca/jfox/Books/Companion/

48. S.; Josse.J; Husson, F. FactoMineR: An R Package for Multivariate Analysis. J. Stat. Soft. 2008, https://doi:25,10.18637/jss.v025.i01.

49. A and Mundt, F. factoextra: Extract and Visualize the Results of Multivariate Data Analyses. R package version 1.0.5. 2017. https://CRAN.R-project.org/package=factoextra.

50. Wickham,H. ggplot2: Elegant Graphics for Data Analysis. 2016. Springer-Verlag New York.

51. R Core Team. R: A language and environment for statistical computing. R Foundation for Statistical Computing, 2019. Vienna, Austria. URL https://www.R-project.org/.

52. Sasaki, K.; Ma, Z.; Khatlani, T. S.; Okuda, M.; Inokuma, H and Onishi, T. Evaluation of feline serum amyloid A (SAA) as an inflammatory marker. J Vet Med Sci 2003, 65, 545-548. https://doi:10.1292/jvms.65.545.

53. Vilhena, H.; Tvarijonaviciute, A., Cerón, J. J.; Pastorinho, M. R.; Martinez-Subiela, S.; Pastor, J, et al. Acute phase proteins response in cats naturally infected by hemotropic mycoplasmas. Comp Immunol Microbiol Infect Dis 2018, 56, 1-5. https://doi.org/10.1016/j.cimid.2017.11.001.

54. Kann, R. K.C.; Seddon, J. M.; Henning, J and Meers, J. Acute phase proteins in healthy and sick cats. Res Vet Sci 2012, 93, 649-654. https://doi.org/10.1016/j.rvsc.2011.11.007.

55. Ottenjann, M.; Weingart, C.; Arndt, G and Kohn, B. Characterization of the anemia of inflammatory disease in cats with abscesses, pyothorax, or fat necrosis. J Vet Inter Med 2006, 20, 1143-1150. https://doi.org/10.1892/08916640(2006)20[1143:cotaoi]2.0.co;2.

56. Thomas J.S. Overview of plasma proteins. In: Feldman BF, Zinkl JG, Jain NC, eds. Schalm's Veterinary Hematology, 5th ed. Baltimore, MD: Lippincott Williams \& Wilkins; 2000:891-898.

57. Vilhena, H.; Tvarijonaviciute, A.; Cerón, J. J.; Figueira, A. C.; Miranda, S.; Ribeiro, A.; et al. Acute phase proteins and biomarkers of oxidative status in feline spontaneous malignant mammary tumours. Vet and Comp Onco/ 2019, 394406. https://doi:10.1111/vco.12486.

58. Kann, R. K. C.; Seddon, J. M.; Kyaw-Tanner, M. T.; Henning, J and Meers, J. Association between feline immunodeficiency virus (FIV) plasma viral RNA load, concentration of acute phase proteins and disease severity. Vet $J$ 2014, 201, 181-183. https://doi.org/10.1016/j.tvjl.2014.01.023.

59. Goldstein, R.E.; Lin, R.C.; Langston, C.E.; Scrivani, P.V.; Erb, H.N.; Barr, S.C. Influence of infecting serogroup on clinical features of leptospirosis in dogs. Vet. Int. Med. 2006, 20, 489-494. https://doi:10.1892/08916640(2006)20489.

60. Pascual, C.; Karzai, W.; Meier-Hellmann, A.; Oberhoffer, M.; Horn, A.; Bredle, D.; et al. Total plasma antioxidant capacity is not always decreased in sepsis. Crit Care Med 1998, 26, 705-709. https://doi.org/10.1097/00003246-19980400000019. 
61. Keegan, R. F and Webb, C. B. Oxidative Stress and Neutrophil Function in Cats with Chronic Renal Failure. J Vet Inter Med 2010, 24, 514-519. https://doi.org/10.1111/j.1939-1676.2010.0498.x.

\section{Figures}

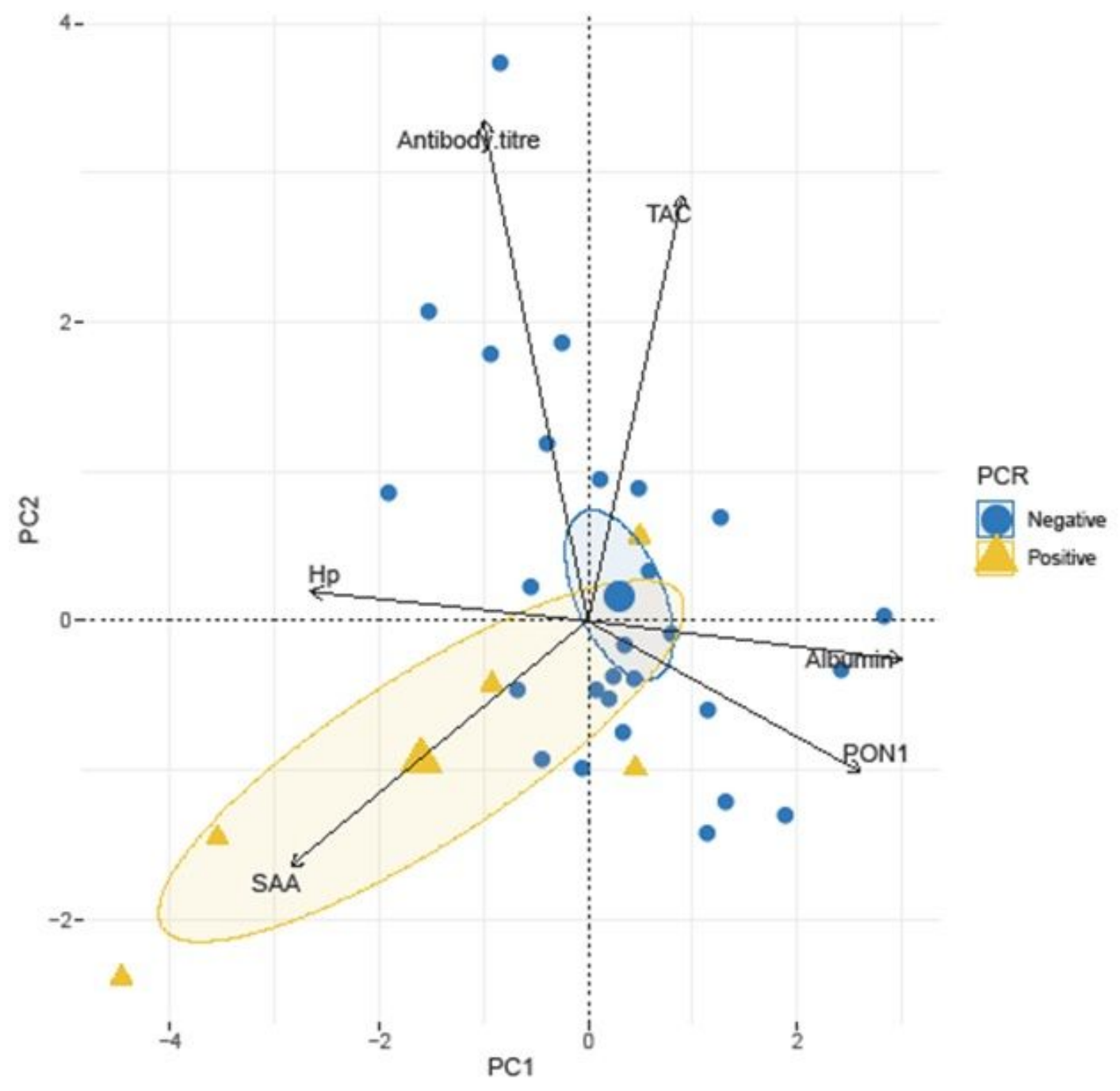

\section{Figure 1}

Biplot of PCR as supplementary variable in the PCA. Biplot representing the relationships between the PCR outcome of the pathogenic leptospires (positive/negative), and PC1 and PC2 dimensions of a PCA exploring the relationships among inflammatory biomarkers (Albumin, PON1, HP and SAA), an antioxidant biomarker (TAC), and antibody level against Leptospira spp. (antibody titre) in 13 cats naturally infected by pathogenic leptospires and 19 leptospires-free cats from Spain. Neither TAC (total antioxidant capacity) nor the antibody titres against Leptospira spp. contributed to the PC1. 


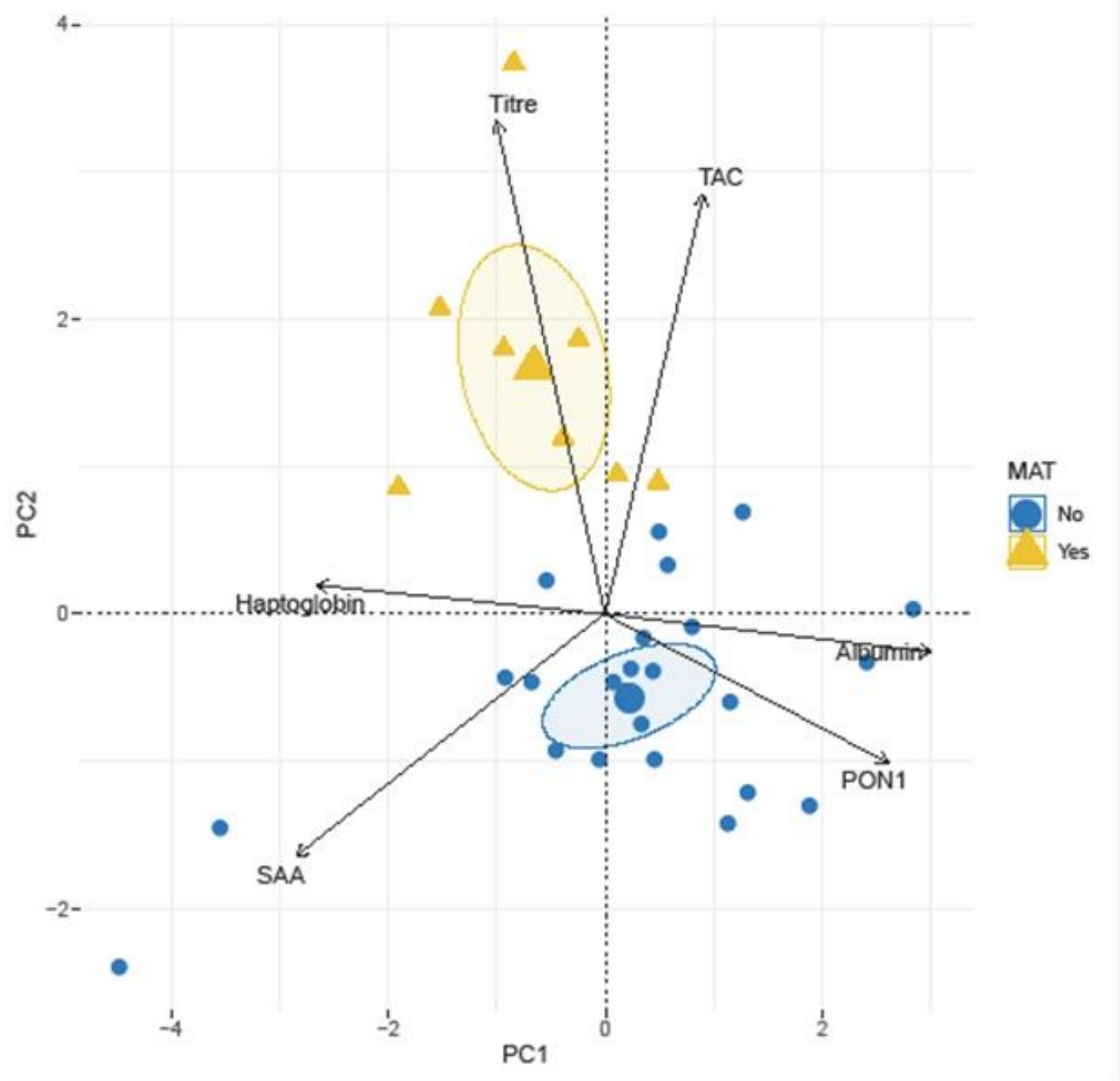

Figure 2

Biplot of MAT as supplementary variable in the PCA. Biplot representing the relationships between MAT outcome (positive/negative), and PC1 and PC2 dimensions of a PCA exploring the relationships among inflammatory biomarkers (Albumin, PON1, HP and SAA), an antioxidant biomarker (TAC), and antibody level against Leptospira spp. (antibody titre) in 13 cats naturally infected by pathogenic leptospires and 19 leptospires-free cats from Spain. Inflammatory biomarkers did not contribute to PC2. 